JSAP: Journal Syariah and Accounting Public

ISSN: 2622-3538

Available Online at https://journal.umgo.ac.id/index.php/JSAP/index

Vol. 3, No. 1 Juli 2020

DOI: $10.31314 /$ jsap.3.1.19-24.2020

\title{
AKUNTABILITAS PENGELOLAAN ANGGARAN PEMBANGUNGAN DESA (Studi Kasus Pada Desa Saruran Kabupaten Enrekang)
}

Idrawahyuni

Universitas Muhammadiyah Makassar, Indonesia

Email; idrawahyuni@unismuh.ac.id

Info Artikel: Diterima: 13 Februari 2020, Disetujui: 23 Februari 2020, Publish 15 Juli 2020

\begin{abstract}
:
This study aims to determine how Accountability Management of Village Development Budget in Saruran Village, Enrekang Regency. This research was conducted at the Saruran Village Office using analysis of effectiveness ratios and efficiency ratios. This type of research is quantitative descriptive. Where data collection used is interview and documentation techniques. The data processed in this study is the report of the Realization of the Village Development Budget in Saruran Village, Enrekang Regency. Data Analysis Techniques used are the Effectiveness Ratio and Efficiency Ratio. The results showed that the efficiency can be said to be very efficient because it produces a ratio level of less than $60 \%$. This means that the Saruran Village Government of Enrekang Regency has been able to realize revenue and budget receipts well.
\end{abstract}

Keywords: Accountability, Village Development Management Budget, effectiveness, efficiency

\section{Abstrak:}

Penelitian ini bertujuan untuk mengetahui bagaimana Akuntabilitas Pengelolaan Anggaran Pembangunan Desa pada Desa Saruran Kabupaten Enrekang. Penelitian ini dilakukan di Desa Saruran dengan menggunakan analisis rasio efektivitas dan rasio efisiensi. Jenis penelitian yang digunakan adalah deskriptif kuantitatif. Dimana pengumpulan data yang digunakan adalah teknik wawancara dan dokumentasi. Data yang di olah dalam penelitian ini adalah laporan Realisasi Anggaran Pembangunan Desa di Desa Saruran Kabupaten Enrekang. Teknik Analisis Data yang digunakan adalah Rasio Efektivitas dan Rasio Efisiensi. Hasil penelitian menunjukkan bahwa efisiensi dapat dikatakan sangat efisien, karena menghasilkan tingkat rasio kurang dari $60 \%$. Ini mengartikan bahwa Pemerintah desa saruran kabupaten enrekang telah mampu merealisasikan pendapatan dan penerimaan anggaran dengan baik.

Kata kunci : Akuntabilitas, Anggaran Pengelolaan Pembangunan Desa, Efektivitas, Efesien

\section{PENDAHULUAN}

Agenda Pembangunan Nasional yang tertuang dalam Perpres No. 2 Tahun 2015 Tentang RPJMN 2015-2019 yaitu "Membangun Indonesia dari pinggiran

dengan memperkuat daerah-daerah dan
desa dalam kerangka NKRI" demi
tercapainya nawacita tersebut maka
pembangunan desa menjadi salah satu
prioritas utama dalam pemerintahan saat ini.

dengan memperkuat daerah-daerah dan tercapainya nawacita tersebut maka prioritas utama dalam pemerintahan saat ini. 
Dasar hukum tentang birokrasi pemerintahan desa mulai dijalankan dan diawasi oleh pihat terkait demi terlaksanannya tata kelola pemerintahan desa yang baik.

Pemerintahaan memiliki peran dalam pengelolaan keuangan publik, yang dimulai dari tata kelola keuangan pusat, daerah, maupun desa. Dalam lingkup terkecil yaitu desa, yang sebagai penyalur antara pemerintah dengan masyarakat dan berhubungan langsung dengan kepentingan dan kebutuhan masyarakat sehingga mempunyai peranan yang sangat strategis yaitu sebagai pelopor sistem demokrasi yang otonom dan berdaulat penuh serta memiliki norma sosial masing-masing. Desa sebagai kawasan otonom diberikan hak-hak istimewa, seperti pengelolaan anggaran desa (Iqsan, 2016).

UU No. 6 tahun 2014 menyebutkan bahwa keuangan desa adalah semua hak dan kewajiban desa yang dapat dinilai dengan uang serta segala sesuatu berupa uang dan barang yang berhubungan dengan pelaksanaan hak dan kewajiban desa. Akuntabilitas dalam pemerintah desa sebagaimana yang diungkapkan oleh Sumpeno (2011: 223) melibatkan pemerintah desa untuk mempertanggungjawabkan kegiatan yang dilaksanakan dalam kaitannya dengan pembangunan desa.

UU Permendagri No. 20 tahun 2018 menyebutkan bahwa keuangan desa dikelola berdasarkan asas-asas transparan, akuntabel, partisipatif serta dilakukan dengan tertib dan disiplin anggaran, APB desa merupakan dasar pengelolaan keuangan desa dalam massa satu tahun anggaran. pemerintah provinsi melakukan pembinaan dan pengawasan terhadap pemberian dan penyaluran dana desa, alokasi dana desa, bagian dari hasil pajak daerah dan retribusi daerah kabupaten/ kota, dan bantuan keuangan kepada Desa. Kemudian Bupati/wati kota melakukan pembinaan dan pengawasan yang dikoordinasikan dengan APIP kabupaten/kota.

\section{METODE PENELITIAN}

Metode analisis yang digunakan dalam penelitian ini, adalah sebagai berikut :

a. Analisis Deskriptif Kualitatif, digunakan untuk menjelaskan Akuntabilitas Pengelolaan Anggaran Pembangunan Desa pada Desa Saruran Kabupaten Enrekang.

b. Analisis efektivitas digunakan sebagai gambaran atau kemampuan pemerintah desa dalam merealisasikan pendapatan asli desa (PADes) yang direncanakan dibandingkan dengan target yang ditetapkan berdasarkan potensi riil desa.

Rasio efektivitas : $\frac{\text { Realisasi penerimaan PADes }}{\text { Anggaran penerimaan PADes }} \times 100 \%$

c. Analisis efisiensi ini digunakan untuk menggambarkan perbandingan antara besarnya biaya yang dikeluarkan dalam memperoleh pendapatan dengan realisasi pendapatan yang diterima.

$$
\text { Rasio efisiensi : } \frac{\text { Biaya belanja }}{\text { Realisasi penerimaan PADes }} \times 100 \%
$$

\section{HASIL DAN PEMBAHASAN}

A. Akuntabilitas

Akuntabilitas dalam pemerintah desa sebagaimana diungkapkan oleh sukasmanto melibatkan kemampuan pemerintah desa untuk mempertanggung jawabkan kegiatan yang dilaksanakan dalam kaitannya dengan masalah pembangunan dan pemerintah desa. Pertanggungjawaban yang dimaksud adalah masalah finansial yang terdapat dalam anggaran pembangunan desa. 
Akuntabilitas dalam pengelolaan dana desa merupakan hal yang harus dilaksanakan oleh pemerintah desa untuk mempertanggung jawabkan penggunaan anggarannya. Dana desa yang diterima sebagian besar dialokasikan untuk pembangunan infrastruktur, menjadi hal yang sangat krusial jika tidak dapat dipertanggung jawabkan.

Nilai akuntabilitas sangat penting diadopsi dalam penyelenggaraan pelayanan public. Hal ini didasarkan pada argumen bahwa eksistensi atau keberadaan suatu Negara, tergantung pada masyarakat itu sendiri. Oleh sebab itu, sudah menjadi kewajiban suatu Negara untuk memberikan pelayanan dengan baik dan bertanggungjawab. akuntabilitas menurut Mardiasmo (2006:3) diartikan sebagai bentuk kewajiban mempertanggungjawabkan keberhasilan atau kegagalan pelaksanaan misi organisasi dalam mencapai tujuan dan sasaran yang telah ditetapkan sebelumnya, melalui suatu media pertanggungjawaban yang dilaksanakan secara periodik.

\section{B. Anggaran}

Anggaran adalah estimasi kinerja yang akan dicapai selama periode waktu tertentu dalam ukuran finansial (Noerdiawan, et al, 2007 : 19). Secara rinci, anggaran sektor publik berisi tentang besarnya belanja yang harus dikeluarkan untuk membiayai program dan aktivitas yang direncanakan serta cara untuk mendapatkan dana untuk membiayai program dan aktivitas tersebut (Mahsun, 2015: 65).

a. Efektivitas

Rasio ini menggambarkan kemampuan pemerintah desa dalam merealisasikan pendapatan asli desa (PADes) yang direncanakan dibandingkan dengan target yang ditetapkan berdasarkan potensi riil desa.
Pemerintah desa dikatakan mampu menjalankan tugasnya apabila rasio yang dicapai minimal 1 sampai 100\% akan tetapi semakin tinggi rasio ini maka itu menunjukkan bahwa kemampuan desa semakin baik (Sumarna, 2017).

b. Efisiensi

Rasio ini menggambarkan perbandingan antara besarnya biaya yang dikeluarkan dalam memperoleh pendapatan dengan realisasi pendapatan yang diterima. Pemerintah desa dikatan efisien apabila rasio yang dicapai kurang dari 1 atau dibawah $100 \%$, maka semakin kecil rasio efisiensi ini maka berarti kinerja pemerintah desa semakin baik. Kemudian pemerintah desa sangat perlu menghitung secara detail besarnya biaya yang dikeluarkan untuk merealisasikan semua pendapatan yang diterima. sehingga dapat diketahui cara memungut pendapatan yang efisien atau yang tidak efisien

\section{Hasil Penelitian}

Pendapatan Desa dimaksud meliputi semua pendapatan desa yang terdiri dari: Pendapatan asli Desa (PAD), bagi hasil pajak Kabupaten/Kota, Bagian dari Retribusi Kabupaten/Kota, Alokasi Dana Desa (ADD), Bantuan Keuangan dari Pemerintahan, Pemerintahan Provinsi, Pemerintahan Kabupaten/Kota dan lainnya.

Table 1: Anggaran Dana Desa 2018

\begin{tabular}{ll}
\hline Keterangan & Jumlah \\
\hline $\begin{array}{l}\text { Alokasi Dana Desa } \\
\text { (ADD) }\end{array}$ & $\mathrm{Rp} 468.428 .000$ \\
\hline Dana Desa (DD) & $\mathrm{Rp} 694.667 .000$ \\
\hline $\begin{array}{l}\text { Jumlah Perkiraan } \\
\text { Pendapatan }\end{array}$ & $\mathrm{Rp} \mathrm{1.163.095.000}$ \\
\hline
\end{tabular}

Sumber: Info grafik APBDesa Saruran (2018) 
Penggunaan keuangan desa secara garis besar digunakan untuk empat bidang, antara lain dalam bidang penyelenggaraan pemerintahan desa, bidang pembangunan desa, bidang pembinaan kemasyarakatan, dan bidang pemberdayaan masyarakat. Adapun temuan dalam penelitian ini dapat diketahui bahwa APBDesa yang berada di Desa Saruran Kabupaten Enrekang dapat diketahui bahwa penggunaan keuangan desa di desa saruran yang terbesar untuk melaksanakan pembangunan desa, yaitu sebesar $64 \%$ hai ini menunjukkan bahwa kegiatan pembangunan desa merupakan hal yang paling dibutuhkan bagi perangkat dan warga masyarakat desa. Porsi terbesar kedua yaitu bidang penyelenggaraan pemerintahan desa, sebanyak $30 \%$. Sedangkan hal-hal yang bersifat kemasyarakatan masih menempati posisi yang belum signifikan, dimana bidang pemberdayaan masyarakat hanya sebesar $4 \%$, dan yang terakhir digunakan untuk pembinaan kemasyarakatan hanya sebesar $2 \%$.

Tahap-tahap yang dilakukan dalam penilaian pengelolaan anggaran desa saruran kabupaten enrekang dilakukan dengan cara analisis rasio yang terdiri dari rasio efektivitas dan rasio efisiensi.

\section{Rasio Efektivitas}

Rasio ini mengambarkan kemampuan pemerintah desa dalam merealisasikan pendapatan asli desa (PADes) yang direncanakan dibandingkan dengan target yang ditetapkan berdasarkan potensi rill desa. Pemerintah desa mampu menjalankan tugasnya apabila rasio yang dicapai minimal 1 sampai $100 \%$ akan tetapi semakin tinggi rasio ini maka itu menunjukkan bahwa kemampuan desa semakin baik (Sumarna, 2017).

Berikut cara untuk menghitung rasio efektivitas:

$$
\begin{aligned}
& \text { Rasio Efektivitas } \\
& =\frac{\text { Realisasi Penerimaan PADes }}{\text { Anggaran Penerimaan PADes }} \times 100 \% \\
& \text { Rasio Efisiensi }=\frac{R p 704.706 .000}{R p 1.163 .095 .000} \times 100 \% \\
& =60 \%
\end{aligned}
$$

2. Rasio Efisiensi

Rasio ini mengambarkan perbandingan antara besarnya biaya yang dikeluarkan dalam memperoleh pendapatan dengan realisasi pendapatan yang diterima. Pemerintah desa dikatakan efisien apabila rasio yang dicapai kurang dari 1 atau dibawah $100 \%$, maka semakin kecil rasio efisiensi ini maka kinerja pemerintah desa semakin baik. Kemungkinan pemerintah desa sangat perlu menghitung secara detail besarnya biaya yang dikeluarkan untuk merealisasikan semua pendapatan yang diterima. Sehingga dapat diketahui cara memungut pendapatan yang efisien atau yang tidak efisien.

Hal ini harus atau perlu dilakukan, walaupun pemerrintah desa sudah berhasil merealisasikan penerimaan pendapatan yang sesuai dengan target yang ditetapkan. Namun biaya untuk memperoleh pendapatan lebih besar dari pencapaian pendapatan dana itu menjadi sia-sia (Sumarna, 2017).

Berikut cara untuk menghitung Rasio Efisiensi:

$$
\begin{gathered}
\text { Rasio Efisiensi } \\
=\frac{\text { Biaya Belanja }}{\text { Realisasi Penerimaan PADes }} \times 100 \% \\
\text { Rasio Efisiensi }=\frac{R p 1.106 .021 .722}{R p 704.706 .000} \times 100 \% \\
=16 \%
\end{gathered}
$$

Pembahasan

Berdasarkan hasil analisis yang telah dilaksanakan diatas maka pengelolaan anggaran Pemerintahan Desa Saruran Kabupaten Enrekang tahun 2018 yang telah 
dianalisis dengan menggunakan analisis rasio yaitu:

\section{Rasio Efektifitas}

Sesuai dengan analisis rasio efektivitas didalam mengukur akuntabilitas pengelolaan anggaran pembangunan desa pada tahun anggaran 2018 berada pada tingkat tidak efektif. Dimana hasil analisis yang telah dilakukan menunjukkan bahwa analisis rasio efektivitas ini di dalam mengukur pengelolaan anggaran pembangunan desa pada satu periode ini belum cukup baik. Karena pada tahun 2018 ini pemerintah di dalam merealisasikan penerimaan pembangunan desanya lebih besar dari pada target yang ditetapkan berdasarkan potensi rill desa. Dimana pada tahun 2018 ini tingkat rasio berada pada tingkat $60 \%$. Melihat hasil analisis rasio ini dapat dikatakan bahwa pemerintah desa di dalam menjalankan tugasnya ditinjau dari rasio efektivitas masih tidak cukup mampu atau masih kurang mampu dalam merealisasikan Anggaran Pembangunan Desanya berdasarkan peraturan yang berlaku.

\section{Rasio efisiensi}

Sesuai dengan analisis rasio efisiensi dalam mengukur Akuntabilitas Pengelolaan Anggaran Pembangunan Desa tahun Anggaran 2018 termasuk dalam kategori tingkat sangat efisien, dimana hasil analisis menunjukkan tingkat rasio yang diperoleh pada tahun 2018 sebesar $16 \%$, hasil rasio efektif di dalam mengukur Akuntabilitas Pengelolaan Anggaran Pembangunan Desa dalam periode tersebut yaitu tahun anggaran 2018 berada pada tingkat rasio sangat efisien karena berada di bawah $60 \%$. Sesuai dengan hasil ke dua analisis diatas dapat diketahui bahwa Akuntabilitas pengelolaan Anggaran Pembangunan Desa pada satu periode ini yaitu tahun anggaran 2018 , dari sisi rasio efektivitas berada pada tingkat rasio sangat efisien.

\section{KESIMPULAN}

Berdasarkan hasil penelitian yang dilakukan, maka dapat ditarik kesimpulan bahwa kebijakan dan peranan akuntabilitas di Desa Saruran Kabupaten Enrekang dalam peningkatan pembangunan dan pengembangan sudah berjalan cukup baik dan sesuai dengan apa yang di harapkan oleh masyarakat setempat dan sudah sesuai dengan peraturan yang mendasari dan laporan pertanggungjawaban Desa Saruran sangat transparansi dan terbuka bagi masyarakat bahkan sudah dilaporkan secara rinci dan detail ke BPD. Dalam hal analisis efektifitas dalam menjalankan tugasnya terutama dalam Pengelolaan Anggaran Pembangunan Desa bisa dikatakan tidak efektivitas karena tingkat rasio sebesar $60 \%$. Dalam hal Pengelolaan Anggaran Pembangunan Desa yang ada di Desa Saruran berdasarkan analisis efisiensi dapat dikatakan sangat efisien, karena menghasilkan tingkat rasio kurang dari $60 \%$. Ini mengartikan bahwa Pemerintah desa saruran kabupaten enrekang telah mampu merealisasikan pendapatan dan penerimaan anggaran dengan baik.

\section{REFERENSI}

Arifiyanto. Febri. Dwi., Taufik, K. (2014). Akuntanbilitas Pengelolaan Alokasi Dana Desa di Kabupaten Jember. Jurnal Riset Akuntansi dan Keuangan. Vol. 2.

Boedijono, Galih. W., Yeni, P., Sandhika, C. B., Nurcahyaning, D. K., Venantya, A. (2019). Efektifitas Pengelolaan Dana Desa untuk Pembangunan dan Pemberdayaan Masyarakat Desa di Kabupaten Bondowoso. Journal. Riset Manajemen dan Bisnis. Vol. 4.

Faradhiba Laily., Nur, D. (2018). Akuntanbilitas Pemerintahan Desa 
dalam Pengelolaan Anggaran Pendapatan dan Belanja Desa (APBDES). Jurnal. Vol. 7.

G.Kartasamita. (1996). Pembangunan Untuk Rakyat, Memadukan Pertumbuhan dan Pemerataan. Jakarta : CIDES.

Iqsan (2016). Transparansi pemerintah desa dalam penyusunan anggaran pendapatan dan belanja desa (APBDes) di Desa Long Nah Kecamatan Muara Ancalong Kabupaten Kutai Timur. eJournal IImu Pemerintahan, 4 (1), 230-240.

Jalan berlubang di Kabupaten Enrekang (Tribun Timur, 2 Maret 2016).

Mahsum Moh, Sulistyowati Firma, Heribertus A. P. (2015). Akuntansi Sektor Publik. Yogyakarta: BPFE.

Masiyah Kholmi. (2016) Akuntanbilitas Pengelolaan Alokasi Dana Desa: Studi di Desa Kedungbetik Kecamatan Kesamben Kabupaten Jombang. Jurnal Ekonomi Bisnis. Vol. 7.

Mas'ud Arifuddin., Safaruddin.,Faiziah. (2017) Persepsi Pengelola KeuanganDesa Dalam Mewujudkan Transparansi dan Akutanbilitas Keuangan Desa di Kecamatan Mawasangka Kabupaten Buton Tengah. Jurnal Akuntansi dan Keuangan. Vol.11.

Maulana Agung., Ahmad, R. Z. H., Ayu, A. (2019). Pengelolaan Alokasi Dana Desa untuk Pemberdayaan Masyarakat: Perspektif Maqashid Syariah. Jurnal Bisnis Ekonomi Islam dan Keuangan. Vol. 9.

Nafida Nasehatum. L., Nur, A. (2017) Akuntanbilitas Pengelolaan Keuangan Dsa di Kabupaten Jombang. Jurnal IImu Akuntansi. Vol. 10.

Nordiawan Deddy, Iswahyudi S.P, Maulidah R. (2007). Akuntansi Pemerintah. Jakarta: Salemba Empat.
Pasal 25 peraturan menteri keuangan nomor 247 tahun 2015 Dana Desa.

Pemendagri nomor 37 tahun 2007 pasal 2 tentang Pedoman Pengelolaan Keuangan Desa.

Pemendagri nomor 130 tahun 2018 Desa ttg kegiatan Kembangunan Sarana dan Prasarana Pembangunan Desa.

Pemendagri nomor 113 tahun 2014 Desa.

Peraturan menteri keuangan R.I Nomor 199/PMK.07/2017 ttg tata cara Pengalokasian Dana Desa.

Rahum. Abu (2015) Pengelolaan Alokasi Dana Desa (ADD) dalam Pembangunan Fisik Desa Karayan Kecamatan Long Ikis Kabupaten Paser. Jurnal IImu Pemerintahan. Vol. 3. 